\title{
Distribution of lymphomas in Turkey: data of 4239 cases from a single institution using the WHO classification
}

\author{
Arzu SAĞLAM ${ }^{1}$ (D) Ece ESİN $^{2}$ (D), Mutlu HAYRAN ${ }^{3}$ (D), Barıș BOYRAZ ${ }^{4}$ (D), Ayşegül ÜNER ${ }^{1 *}$ (D) \\ ${ }^{1}$ Department of Pathology, School of Medicine, Hacettepe University, Ankara, Turkey \\ ${ }^{2}$ Department of Medical Oncology, School of Medicine, Hacettepe University, Ankara, Turkey \\ ${ }^{3}$ Department of Preventive Oncology, School of Medicine, Hacettepe University, Ankara, Turkey \\ ${ }^{4}$ School of Medicine, Hacettepe University, Ankara, Turkey
}

Received: 18.04 .2018

- $\quad$ Accepted/Published Online: 08.08 .2018

- Final Version: 31.10 .2018

Background/aim: Lymphoma cases diagnosed at one of the largest tertiary reference centers in Turkey were reviewed and findings were compared to those reported from other regions of the world.

Materials and methods: Lymphomas diagnosed between 2000 and 2017 in the pathology laboratory of Hacettepe University were identified. A total of 4239 cases were analyzed. The WHO 2008 classification was used.

Results: Hodgkin lymphomas accounted for almost $20 \%$ of cases. T-cell lymphomas were much more frequent (23\% of our nonHodgkin lymphoma (NHL) cases) in comparison to all other regions of the world. The reason for this difference was the high frequency of mycosis fungoides (MF) cases. We had significantly more cases of high-grade B-cell lymphoma (43.9\% of NHLs) and fewer cases of low-grade B-cell lymphoma (33.5\% of NHLs) in comparison to the rates of developed regions of the world and the reverse was true when compared to developing parts of the world. Burkitt lymphoma frequency ( $4 \%$ of NHLs) was also higher than in most parts of the world.

Conclusion: Our data reveal that the frequency of MF, Burkitt lymphoma, and Hodgkin lymphoma are considerably higher, whereas follicular lymphoma rates are considerably lower than in most other parts of the world.

Key words: Classification, lymphomas, Turkey, non-Hodgkin lymphoma, epidemiology

\section{Introduction}

Lymphoma is a disease with diverse subtypes, which tend to differ worldwide from region to region. Several international projects have reported significant differences in the relative frequencies of NHL subtypes around the world (1). Studies are still being reported from all over the world about the various subtypes of lymphoma, mostly as part of the International Non-Hodgkin Lymphoma Classification Project. Although some factors of underlying lymphoma development have been identified (such as viral and bacterial infections, use of immunosuppressive drugs, diet, lifestyle, and exposure to various chemicals), the etiology of lymphomas largely remains unknown and it is hoped that better knowledge of the distribution of lymphomas could help shed light on factors underlying lymphoma development.

Turkey is a transcontinental country that overlies both West Asia and East Europe and has been an important

\footnotetext{
*Correspondence: unera@hacettepe.edu.tr
}

intersection between the two continents for centuries. The Turkish population is hence a very heterogeneous population, which could reflect on disease epidemiology. Alkan et al. showed that genetic variation within the Turkish population is generally clustered with European populations, while also harboring signatures of admixture from African and East Asian populations (2).

The incidences of the various subtypes of lymphoma in Turkey are largely unknown and no comprehensive study has so far been performed. The only data belong to a study presented at a hematopathology meeting incorporating a series of about 3700 cases reported over a time span of 5 years belonging to 5 major institutions in Turkey. The data, however, were gathered in 2000 and were based on a now relatively old World Health Organization (WHO) classification. The WHO classification of lymphomas has changed considerably since and various new entities have emerged (3). 
In this study we reviewed lymphoma cases diagnosed at the Hacettepe University Faculty of Medicine, one of the largest tertiary reference centers in Turkey, in hope of shedding some light on this deficit and to compare data to those reported from other regions of the world. Morphological subtypes and basic clinicopathological characteristics (such as age, sex, and localization) of 4239 cases were analyzed.

\section{Materials and methods}

\subsection{Choice of cases}

All lymphoproliferative neoplasms diagnosed between the years of 2000 and 2017 at the pathology laboratory of the Hacettepe University Faculty of Medicine were analyzed. A total of 4239 cases were identified. Pediatric cases were underrepresented since most are sent to the pathology laboratory of the Hacettepe Pediatric Hospital.

The cases had been diagnosed by four hematopathologists working at the institution during the years included in the study using a wide panel of immunohistochemistry as deemed necessary (CD20, CD3, CD30, CD19, CD4, CD8, granzyme-B, TIA-1, CD5, cyclin D1, SOX-11, CD38, CD138, kappa, lambda, CD2, CD34, CD56, PD-1, MUM-1, CD10, Ki-67, Bcl-6, Bcl-2, PAX-5, CD15, EMA, ALK, EBER, CD68, CD163, MPO, CD43, TdT, CD99, CD123, CD23, CD33, CD79a, c-myc). EBER in situ hybridization was only available during the last 5 years.

\subsection{Analysis of cases}

The WHO 2008 classification was used and cases diagnosed before the WHO 2008 classification was put into effect were reclassified accordingly. Age, sex, and localization of the biopsy specimen were the clinical data acquired for the study. The cases were initially grouped into Hodgkin lymphoma (HL), non-Hodgkin lymphoma (NHL), grayzone lymphomas with features between HL and diffuse large B-cell lymphoma (DLBCL), and unclassifiable cases. HLs were further separated into classical HL (cHL) and nodular lymphocyte-predominant HL (NLPHL). NHL cases were later grouped parallel to those of previous studies and this allowed statistical comparison (4-8). Chronic lymphocytic leukemia/small lymphocytic lymphoma (CLL/SLL), follicular lymphoma (FL), marginal zone lymphoma (MZL: nodal, splenic, and extranodal), mantle cell lymphoma (MCL), lymphoplasmacytic lymphoma (LPL), splenic B-cell lymphoma/leukemia unclassifiable, and all cases of unclassifiable low-grade B-cell lymphomas formed the group designated "low-grade B-cell lymphoma" (LGBCL), whereas B-cell lymphoblastic lymphoma (LBL), Burkitt lymphoma (BL), DLBCL NOS, EBV-associated DLBL of the elderly, T-cell/histiocyte-rich large B-cell lymphoma (THRLBCL), B-cell lymphoma with features in between Burkitt and DLBCL, plasmablastic lymphoma, primary mediastinal large B-cell lymphoma (PMLBCL), and all cases of unclassifiable high-grade B-cell lymphoma were grouped under the general heading "high-grade B-cell lymphoma" (HGBCL). There was also a group of B-cell lymphomas (BCLs) that could not be subgrouped as LGBCL or HGBCL. Those T-cell lymphomas (TCL) that were relatively more common were classified separately, namely anaplastic large cell lymphoma (ALCL), peripheral T-cell lymphoma, NOS (PTCL), angioimmunoblastic T-cell lymphoma (AITCL), extranodal NK-/T-cell lymphoma, nasal type, enteric T-cell lymphomas, T-cell large granular lymphocytic leukemia (LGL), hepatosplenic T-cell lymphoma, subcutaneous panniculitis-like T-cell lymphoma (SPTCL), mycosis fungoides (MF), and T-cell lymphoblastic lymphoma (T-LBL). The rarer entities and those that could not be further characterized were lumped under the general heading of "mature T/NK cell neoplasms, other". Cutaneous T-cell lymphomas were also included under the general "mature T/NK cell neoplasms, other" heading, except for MF, which constituted a considerable amount of the cases and was classified separately. The cases were later regrouped into fewer categories (including PTCL, extranodal NK/T cell lymphoma (ENKL), nasal type, T-LBL, ALCL, AITCL, MF, adult T-cell leukemia/lymphoma (ATCL), and mature T/NK cell neoplasms, other) parallel to previous studies to allow statistical comparison (4-8). Cases of composite lymphoma were classified according to the clinically more relevant high-grade component.

\subsection{Comparison with data from other countries}

Our resulting data were compared with those of other countries around the word. To this end, data gathered from West Europe (WE), North America (NA), Central South America (CSA), the Far East (FE), North Africa/ the Middle East/India (NAF/ME/IN), South Africa (SAF), Southeast Europe (SEE), and the combined data of WE and NA under the heading "developed" and the combined data of CSA, the FE, NAF/ME/IN, SAF, and SEE under the heading "developing" were used. These data were acquired from previously published studies (4-8) that were executed as part of the International NHL classification project.

\subsection{Statistical analysis}

The one-sample chi-square test was used for comparing the sex and histologic subtype proportions with selected regions, and the one-sample Wilcoxon signed rank test was used to compare the age distribution with the reference median values from the selected regions of the world. Stata and R software were used for the statistical analyses. A P-value cut-off of 0.05 was used to infer statistical significance. 


\section{Results}

\subsection{Age, sex, and localization}

Ages of the patients ranged between 1 and 96 years with a median of 51 years (47 cases lacked age information). Pediatric cases were underrepresented due to the fact that most are sent to the Children's Hospital Pathology Laboratory. Precursor/lymphoblastic lymphomas had a lower median patient age of around 20 years, whereas LGBCL and AITCL had a higher median age of 59 and 61.5 , respectively (Table 1 ).

Of the patients, $42.5 \%$ were female and $57.5 \%$ were male. Males predominated, the overall male to female (M/F) ratio being 1.13 . This predominance was most exaggerated in mantle cell lymphoma with an $\mathrm{M} / \mathrm{F}$ ratio of 3.6, followed by Burkitt lymphoma (M/F ratio: 2.3 ) and KLL/SLL (M/F ratio: 1.7$)$. There was a female predominance most notably in PMLBCL (M/F: 0.5), as well as B-LBL (M/F: 0.9), FL (M/F: 0.9), MZL (M/F: 0.8), and AITCL (M/F: 0.9).

Of the cases, $49.1 \%$ were localized to lymph nodes, $10.7 \%$ to the skin, $8.4 \%$ to the gastrointestinal tract (about half of which was located to the stomach), $7.4 \%$ to the bone marrow, and the rest to a wide variety of extranodal sites. MF cases accounted for $64.5 \%$ of the cases localized to the skin.

\subsection{Distribution of cases}

Twenty-six of the 4239 cases $(0.6 \%)$ were unclassified mainly due to sample inadequacy. HLs constituted $19.7 \%$ $(n=833)$ of the cases, $91 \%$ of which were $\mathrm{cHL}$. There were 11 cases that were considered gray-zone lymphomas, in which the distinction between HL and NHL could not be made. NHL constituted $79.8 \%(n=3369)$ of the cases. Within the NHLs $(\mathrm{n}=3369)$, BCL comprised the majority (77.8\%, 2633 cases) and TCL made up about one-fifth of all NHLs (22.2\%, 747 cases), almost half of which were MF cases $(n=324)$. Distribution of the lymphomas with regard to basic subtypes is given in Table 2 .

\subsubsection{B-Cell lymphomas}

There were 3293 cases of NHL, the majority of which were BCL. Seventy-six cases $(2.3 \%$ of the NHL cases, $1.8 \%$ of the total number of cases) of BCL could not be classified further.

Most of the biopsies were from the lymph node, followed by the stomach (about 10\%), the rest of the gastrointestinal tract $(6.6 \%)$, the central nervous system (6.9\%), and various other sites such as the liver, Waldeyer's ring, the genitourinary system, bone marrow, bone, skin, breast, lungs, soft tissue, the vertebral/paraspinal region, adrenal glands, the parotid gland, and the heart.

HGBCL accounted for almost half of the BCL cases, the detailed distribution of which is shown in Table 3. A total of 1042 cases of DLBCL were identified, 613 of which had available data to permit further classification into germinal center type (342 cases, 55.8\%) versus activated B-cell phenotype (271 cases, $44.2 \%$ ). Twenty-eight cases of EBV-associated HGBCL were identified. These are probably underrepresented and actually account for more of the HGBCLs since EBER in situ hybridization was only available during the last 5 years of the study period. EBV-associated cases related to immunosuppression and posttransplantation period were also included among the EBV-associated HGBCL cases.

There were 1102 cases of LGBCL (Table 4). Pediatric MZL and FL are probably underestimated, having been more clearly delineated only during the last few years and due to the fact that pediatric lymphomas as a group are underrepresented in the cohort. About half of the cases had lymph node presentation, and one-fifth were diagnosed via a bone marrow biopsy, followed by the orbital/periorbital region $(6.2 \%)$, stomach $(5.4 \%)$, and spleen $(3.9 \%)$.

\subsubsection{T-Cell lymphomas}

Almost half of the mature T/NK cell neoplasms were MF cases. All but $3 \mathrm{MF}$ cases were biopsies from the skin; those 3 were from the lymph node. When cases of MF were excluded the remainder of the TCL cases predominantly presented with lymphadenopathy (53.2\%), followed by skin (13.8\%), nasal and Waldeyer's region (5.6\% and $4.1 \%$, respectively), gastrointestinal tract $(7.7 \%)$, bone marrow (3.5\%), spleen $(2.4 \%)$, and liver involvement (1.2\%), not to mention various other uncommon sites such as the orbit, breast, bone, central nervous system, mediastinum, lung, retroperitoneum, and ovary. ALCL constituted the majority of cases of mature T/NK cell neoplasms (Table 5).

\subsection{Comparison of findings with data from other regions of the world}

\subsubsection{Hodgkin lymphoma}

The distribution of HL cases was compared with data from other studies. Within our study population HL formed a higher proportion of cases of lymphoma in comparison to the United States, Australia, Southwest China, and Poland and this difference was statistically significant (9-13) (Table $6)$. This figure was lower than that reported in Iran and this difference was likewise statistically significant (12). cHL accounted for $91.5 \%$ of HL cases. This figure was similar to that of Iran, but lower than that of other countries, the difference being statistically significant. NLPHL hence formed a higher proportion of cases of HL with respect to data from SW China, Australia, Poland, and also the United States (the difference being less pronounced), but similar to data from Iran.

\subsubsection{Non-Hodgkin lymphoma}

Data regarding cases of NHLs were compared to findings reported from other regions of the world. In order to do this we modified our data parallel to that of recent studies (4-8) that were executed as part of the International NHL 
Table 1. Age distribution of main lymphoma subtypes.

\begin{tabular}{|l|l|l|l|l|l|}
\hline & Minimum & Maximum & Median & Percentile 25 & Percentile 75 \\
\hline B-Lymphoblastic lymphoma & 3 & 86 & 24 & 13.0 & 48.0 \\
\hline T-Lymphoblastic lymphoma & 2 & 70 & 20 & 14.0 & 31.0 \\
\hline High-grade B-cell lymphoma & 1 & 96 & 53 & 38.0 & 65.0 \\
\hline Low-grade B-cell lymphoma & 5 & 96 & 59 & 49.0 & 68.0 \\
\hline Mature T/NK-cell neoplasms & 6 & 93 & 49 & 34.0 & 61.0 \\
\hline Mycosis fungoides & 8 & 88 & 49 & 37.0 & 61.0 \\
\hline Classical Hodgkin lymphoma & 1 & 85 & 32 & 22.0 & 47.0 \\
\hline Anaplastic large cell lymphoma & 6 & 93 & 39 & 25.0 & 55.0 \\
\hline Extranodal NK/T-cell lymphoma, nasal type & 19 & 69 & 44 & 32.0 & 56.0 \\
\hline Angioimmunoblastic T-cell lymphoma & 7 & 88 & 61.5 & 54.0 & 69.0 \\
\hline
\end{tabular}

Table 2. Distribution of lymphomas with regard to main subtypes.

\begin{tabular}{|l|l|l|}
\hline & $\mathrm{n}$ & $\%$ \\
\hline Hodgkin lymphoma & 833 & 19.7 \\
\hline Classical Hodgkin lymphoma & 762 & 18.0 \\
\hline Nodular lymphocyte-predominant Hodgkin lymphoma & & 1.7 \\
\hline Gray-zone lymphoma & 11 & 0.3 \\
\hline Non-Hodgkin lymphoma & 3369 & 79.8 \\
\hline B-Cell lymphomas & 2633 & 62.2 \\
\hline B-Lymphoblastic lymphoma & 49 & 1.2 \\
\hline High-grade B-cell lymphoma & 1395 & 32.9 \\
\hline Low-grade B-cell lymphoma & 1102 & 26.0 \\
\hline B-Cell lymphoma unclassifiable & 76 & 1.8 \\
\hline T-Cell lymphomas & 747 & 17.6 \\
\hline T-Lymphoblastic lymphoma & 83 & 2.0 \\
\hline Mycosis fungoides & 324 & 7.6 \\
\hline All other T-cell lymphomas & 340 & 8.0 \\
\hline Lymphoma, unclassified & 26 & 0.6 \\
\hline Total & 4239 & 100.1 \\
\hline
\end{tabular}

classification project. Cases that could not be satisfactorily classified as either BCL or TCL $(n=76)$ were excluded from the analysis. This resulted in a total of 3293 NHL cases. Cases of hairy cell leukemia and pediatric FL and MZL were included within the "LGBCL unclassifiable" group. Since we had not included plasmacytomas in our study, the data present in other studies were inserted with the "LGBCL unclassifiable" cases. Table 7 shows the detailed frequency distribution of NHLs in Turkey and other regions of the world. A heat-map summarizing the differences in frequency and distribution of NHL cases in
Turkey compared to findings of other regions of the world is presented (Figure).

Our most prominent finding was that TCLs were much more frequent in comparison to all other regions of the world, this difference being statistically highly significant (chi-square, $\mathrm{P}<0.001$ ). TCLs constituted almost $23 \%$ of our cases, a figure even higher than that in the Far East (18\%). Within the TCLs, MF frequency was significantly higher with respect to almost all other regions of the world, with the exception of North America, for which our TCL distribution was very similar, the only exception 
Table 3. Distribution of high-grade B-cell lymphomas (HGBCL).

\begin{tabular}{|l|l|l|l|}
\hline & $\mathrm{n}$ & $\begin{array}{l}\% \text { among } \\
\text { all cases }\end{array}$ & $\begin{array}{l}\% \text { among } \\
\text { HGBCLs }\end{array}$ \\
\hline Diffuse large B-cell lymphoma, NOS & 1042 & 24.6 & 72.2 \\
\hline Burkitt lymphoma & 131 & 3.1 & 9.1 \\
\hline High-grade B-cell lymphoma-Burkitt like & 81 & 1.9 & 5.6 \\
\hline EBV-associated high-grade B-cell lymphoma & 28 & 0.7 & 1.9 \\
\hline T-Cell/histiocyte-rich large B-cell lymphoma & 53 & 1.3 & 3.7 \\
\hline Primary mediastinal large B-cell lymphoma & 36 & 0.8 & 2.5 \\
\hline Plasmablastic lymphoma & 6 & 0.1 & 0.4 \\
\hline Diffuse large B-cell lymphoma, leg type & 4 & 0.1 & 0.3 \\
\hline ALK-positive large B-cell lymphoma & 2 & $<0.1$ & 0.1 \\
\hline B-Lymphoblastic lymphoma & 49 & 1.6 & 3.4 \\
\hline Unclassifiable B-cell lymphoma & 12 & 0.3 & 0.8 \\
\hline Total & 1444 & 34.1 & 100 \\
\hline
\end{tabular}

Table 4. Distribution of low-grade B-cell lymphomas (LGBCLs).

\begin{tabular}{|l|l|l|l|}
\hline & $\mathrm{n}$ & $\begin{array}{l}\% \text { among } \\
\text { all cases }\end{array}$ & $\begin{array}{l}\% \text { among } \\
\text { LGBCLs }\end{array}$ \\
\hline Follicular lymphoma & 313 & 7.4 & 28.4 \\
\hline Chronic lymphocytic leukemia/ small lymphocytic lymphoma & 206 & 4.9 & 18.7 \\
\hline Marginal zone lymphoma, extranodal & 204 & 4.8 & 18.5 \\
\hline Mantle cell lymphoma & 134 & 3.2 & 12.2 \\
\hline Marginal zone lymphoma, nodal & 61 & 1.4 & 5.5 \\
\hline Marginal zone lymphoma, splenic & 32 & 0.8 & 2.9 \\
\hline Hairy cell leukemia & 35 & 0.8 & 3.2 \\
\hline Low-grade B-cell lymphoma, unclassifiable & 89 & 2.1 & 8.1 \\
\hline Lymphoplasmacytic lymphoma & 22 & 0.5 & 1.9 \\
\hline Pediatric marginal zone lymphoma & 3 & 0.1 & 0.3 \\
\hline Pediatric follicular lymphoma & 3 & 0.1 & 0.3 \\
\hline Total & 1102 & 26 & 100 \\
\hline
\end{tabular}

being T-LBL. T-LBL frequency was significantly lower than in almost all other regions except CSA $(\mathrm{P}<0.001)$, for which it was similar. ATCL and ENKL were significantly lower than in WE. AITCL, ATCL, ALCL, and PTCL were significantly lower than in developed countries.

The distribution of LGBCL versus HGBCL was similar to that of CSA, SAF, and developing countries in general. We had significantly more cases of HGBCL and fewer cases of LGBCL in comparison to developed regions of the world and SEE (chi-square, $\mathrm{P}<0.001$ ). The reverse was true when compared to the FE and NAF/ME/IN; we then had significantly fewer cases of HGBCL and more cases of LGBCL (chi-square, $\mathrm{P}<0.001$ ).
Among the LGBCLs, one other common theme was that we had fewer cases of FL in comparison to almost all other regions of the world with the exception of SEE; this difference was also statistically significant (chi-square, $\mathrm{P}$ $<0.001$ ).

Unclassifiable LGBCLs were also significantly more common than in most other regions with the exception of FE and SAF (chi-square, $\mathrm{P}<0.001$ ).

One other entity that differed significantly from all other regions of the world was Burkitt lymphoma, as our frequency of it was significantly higher (chi-square, $\mathrm{P}<$ 0.001), the only exception being CSA. Unclassifiable cases of HGBCL, on the other hand, were lower in comparison 


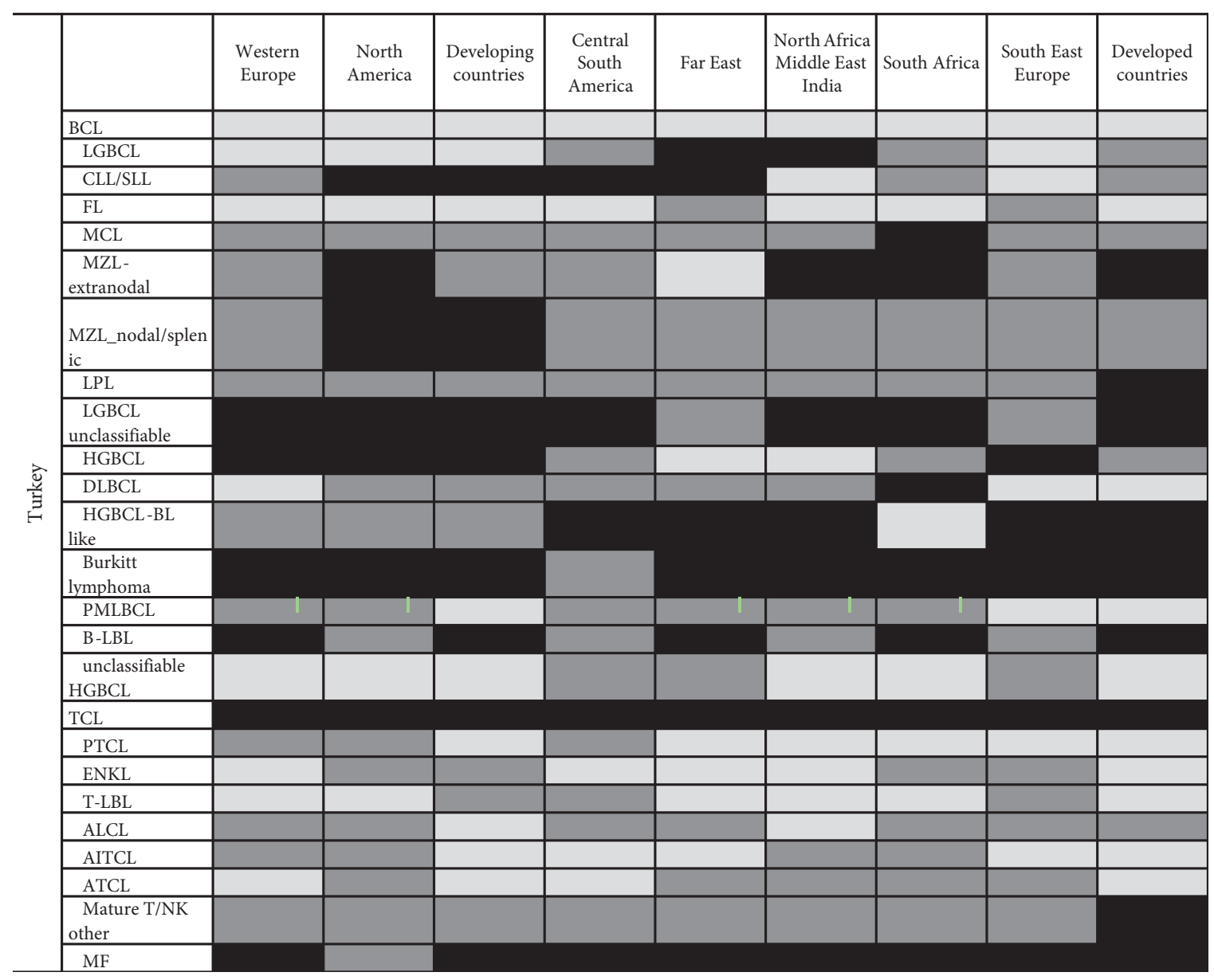

Figure. Heat-map demonstrating the differences in frequency distribution of NHL cases in Turkey compared to findings from other regions of the world. Black: Statistically significant higher rate, light gray: statistically significant lower rate, dark gray: no statistically significant difference.

to most other parts of the world (with the exception of CSA, Europe, and FE) (chi-square, $\mathrm{P}<0.001$ ).

The median age of presentation of NHLs was significantly lower when compared to developing countries (WE and NA), CSA, and SEE, but similar to that of the FE (Table 8).

Turkey had a significantly higher number of male patients in comparison to developed countries (WE and NA), CSA, and SEE. The number of female patients, on the other hand, was significantly higher in comparison to the FD and NA/ME/IN. The M/F ratio was similar to that of SAF and developing countries in general (Table 9).

\section{Discussion}

Epidemiologic studies are an important source for determining the pathogenesis of diseases. Turkey is situated at an intersection between West Asia and East Europe.
The Turkish population is genetically very heterogeneous (2). Being an intercontinental country, environmental heterogeneity also exists. These factors no doubt reflect on disease epidemiology.

There are few up-to-date and extensive studies with regard to distribution of subtypes of lymphoma in Turkey (14-18). The Hacettepe University Hospital is a leading tertiary center in Turkey and receives patients from all over the country. Having a prominent oncology hospital, it is an especially reputable center for oncologic cases. Considering that most cases of lymphomas diagnosed in Turkey are referred to tertiary centers for treatment plans, we believe that our data are for the most part representative in giving an overall idea of the general Turkish population.

We identified 4239 lymphoma cases diagnosed over a period of 17 years at the Hacettepe University Faculty of Medicine. All cases were included in the study. We 
Table 5. Distribution of T-cell lymphomas (TCLs).

\begin{tabular}{|l|l|l|l|}
\hline & $\mathrm{n}$ & $\begin{array}{l}\% \text { among } \\
\text { all cases }\end{array}$ & $\begin{array}{l}\% \text { among } \\
\text { TCLs }\end{array}$ \\
\hline Anaplastic large cell lymphoma & 108 & 2.5 & 14.5 \\
\hline Peripheral T-cell lymphoma, NOS & 96 & 2.3 & 12.9 \\
\hline Mature T/NK-cell neoplasms, other & 43 & 1.2 & 5.7 \\
\hline Angioimmunoblastic T-cell lymphoma & 34 & 0.8 & 4.6 \\
\hline Extranodal NK/T cell lymphoma, nasal type & 30 & 0.7 & 4 \\
\hline Intestinal T-cell lymphoma & 4 & 0.1 & 0.5 \\
\hline Large granular lymphocytic leukemia & 3 & 0.1 & 0.4 \\
\hline Hepatosplenic T-cell lymphoma & 3 & 0.1 & 0.4 \\
\hline Mycosis fungoides & 324 & 7.6 & 43.4 \\
\hline T-Lymphoblastic lymphoma & 83 & 2 & 11.1 \\
\hline T-Cell lymphoma unclassifiable & 19 & 0.4 & 2.5 \\
\hline Total & 747 & 17.6 & 100 \\
\hline
\end{tabular}

Table 6. The distribution of HL cases and comparison with data from other studies.

\begin{tabular}{|c|c|c|c|c|c|c|c|c|c|c|c|c|}
\hline & \multicolumn{2}{|c|}{ Turkey } & \multicolumn{2}{|l|}{ Iran } & \multicolumn{2}{|c|}{ South West China } & \multicolumn{2}{|c|}{ Australia } & \multicolumn{2}{|l|}{ Poland } & \multicolumn{2}{|c|}{ United States } \\
\hline & $\mathrm{n}$ & $\%$ & $\mathrm{n}$ & $\%$ & $\mathrm{n}$ & $\%$ & $\mathrm{n}$ & $\%$ & $\mathrm{n}$ & $\%$ & $\mathrm{n}$ & $\%$ \\
\hline Lymphoma & 4239 & 100 & 1085 & 100 & 6382 & 100 & 128,295 & 100 & 11,702 & 100 & 136,960 & 100 \\
\hline $\mathrm{HL}$ & 833 & 19.7 & 333 & 30.7 & 833 & 13.1 & 9542 & 7.4 & 1567 & 13.4 & 8500 & 6.2 \\
\hline NHL & 3406 & 80.3 & 752 & 69.3 & 5549 & 86.9 & 118,753 & 92.6 & 10,135 & 86.6 & 128,460 & 93.8 \\
\hline $\mathrm{cHL}$ & 762 & 91.5 & 302 & 90.7 & 798 & 95.6 & 9307 & 97.5 & 1478 & 94.3 & 7950 & 93.5 \\
\hline NLPHL & 71 & 8.5 & 31 & 9.3 & 35 & 4.4 & 235 & 2.5 & 89 & 5.7 & 550 & 6.5 \\
\hline \multicolumn{13}{|c|}{ P-values (ref: Turkey) } \\
\hline HL/NHL & & & \multicolumn{2}{|c|}{$<0.001$} & \multicolumn{2}{|c|}{$<0.001$} & \multicolumn{2}{|l|}{$<0.001$} & \multicolumn{2}{|l|}{$<0.001$} & \multicolumn{2}{|l|}{$<0.001$} \\
\hline cHL/NLPHL & & & \multicolumn{2}{|l|}{0.67} & \multicolumn{2}{|c|}{$<0.001$} & \multicolumn{2}{|l|}{$<0.001$} & \multicolumn{2}{|l|}{0.008} & \multicolumn{2}{|l|}{0.023} \\
\hline
\end{tabular}

HL: Hodgkin lymphoma, NHL: non-Hodgkin lymphoma, cHL: classical Hodgkin lymphoma, NLPHL: nodular lymphocyte-predominant Hodgkin lymphoma.

compared the data to those from other parts of the world, mostly extrapolated from studies that were part of the International NHL classification project (4-8).

It should be kept in mind that most of these studies included a selected number of cases from different institutes and not the whole ensemble of cases at a given institution, as was the case with our study. This could have caused some bias. An important shortcoming of our study was the fact that lymphomas belonging to the pediatric age group were underrepresented due to the fact that some of them are sent to the pathology laboratory of the Children's Hospital.
The most prominent finding was that $\mathrm{T}$-cell lymphomas were much more frequent in comparison to all other regions of the world; this difference was statistically highly significant (chi-square, $\mathrm{P}<0.000$ ). T-cell lymphomas constituted almost $23 \%$ of our NHL cases, a figure even higher than that in the Far East (18\%). The reason for this difference was the high frequency of MF among our cases. Considering that MF patients usually have multiple biopsies, it is important to note that this was not a confounding factor and that only one biopsy from a patient was included in our analysis. All other subtypes of TCL, on the other hand, actually had a decreased frequency with respect to figures from other regions of the world. 
Table 7. Detailed frequency distribution of non-Hodgkin lymphomas in Turkey and other regions of the world.

\begin{tabular}{|c|c|c|c|c|c|c|c|c|c|c|c|c|c|c|c|c|c|c|c|c|}
\hline & \multicolumn{2}{|c|}{ Turkey } & \multicolumn{2}{|l|}{ WE } & \multicolumn{2}{|l|}{ NA } & \multicolumn{2}{|c|}{ Developed } & \multicolumn{2}{|c|}{ CSA } & \multicolumn{2}{|l|}{$\mathrm{FE}$} & \multicolumn{2}{|c|}{\begin{tabular}{|l|}
$\mathrm{NAF} / \mathrm{ME} /$ \\
$\mathrm{IN}$ \\
\end{tabular}} & \multicolumn{2}{|c|}{ SAF } & \multicolumn{2}{|l|}{ SEE } & \multicolumn{2}{|c|}{ Developing } \\
\hline & $\mathrm{n}$ & $\%$ & $n$ & $\%$ & $\mathrm{n}$ & $\%$ & $\mathrm{n}$ & $\%$ & $\mathrm{n}$ & $\%$ & $\mathrm{n}$ & $\%$ & $\mathrm{n}$ & $\%$ & $\mathrm{n}$ & $\%$ & $\mathrm{n}$ & $\%$ & $\mathrm{n}$ & $\%$ \\
\hline BCL & 2546 & 77.4 & 527 & 90.9 & 361 & 90.5 & 888 & 90.7 & 797 & 87.1 & 552 & 82 & 773 & 86.9 & 418 & 85.8 & 542 & 91.1 & 3082 & 86.6 \\
\hline LGBCL & 1102 & 33.5 & 316 & 54.5 & 224 & 56.3 & 540 & 55.1 & 364 & 39.8 & 183 & 27.2 & 253 & 28.4 & 167 & 34.2 & 278 & 46.8 & 1245 & 35.1 \\
\hline CLL/SLL & 206 & 6.3 & 50 & 8.6 & 19 & 4.8 & 69 & 7 & 28 & 3.1 & 18 & 2.7 & 62 & 7 & 41 & 8.4 & 67 & 11.3 & 216 & 6.1 \\
\hline $\mathrm{FL}$ & 313 & 9.5 & 116 & 20 & 134 & 33.6 & 250 & 25.5 & 189 & 20.7 & 63 & 9.4 & 110 & 12.4 & 88 & 18.1 & 94 & 15.8 & 544 & 15.3 \\
\hline MCL & 134 & 4.1 & 48 & 8.3 & 28 & 7 & 76 & 7.8 & 46 & 5 & 24 & 3.6 & 20 & 2.2 & 9 & 1.8 & 35 & 5.9 & 134 & 3.8 \\
\hline MZL extranodal & 204 & 6.2 & 61 & 10.5 & 25 & 6.3 & 86 & 8.8 & 64 & 7 & 46 & 6.8 & 24 & 2.7 & 12 & 2.5 & 39 & 6.6 & 185 & 5.2 \\
\hline MZL nodal/splenic & 93 & 2.9 & 22 & 3.8 & 7 & 1.8 & 29 & 3 & 24 & 2.6 & 15 & 2.2 & 18 & 2 & 9 & 1.8 & 22 & 3.7 & 88 & 2.5 \\
\hline LPL & 22 & 0.7 & 8 & 1.4 & 6 & 1.5 & 14 & 1.4 & 2 & 0.2 & 2 & 0.3 & 1 & 0.1 & 4 & 0.8 & 3 & 0.5 & 12 & 0.3 \\
\hline LGBCL unclassifiable & 130 & 4 & 11 & 1.9 & 5 & 1.3 & 16 & 1.6 & 11 & 1.2 & 15 & 2.2 & 18 & 2 & 4 & 0.8 & 18 & 3 & 66 & 1.9 \\
\hline HGBCL & 1444 & 43.9 & 211 & 36.4 & 137 & 34.3 & 348 & 35.5 & 433 & 47.3 & 369 & 54.7 & 520 & 58.4 & 191 & 51.4 & 264 & 44.4 & 1777 & 51.6 \\
\hline DLBCL & 1135 & 34.4 & 187 & 32.2 & 117 & 29.3 & 283 & 28.9 & 357 & 39 & 327 & 48.6 & 420 & 47.2 & 117 & 36.3 & 231 & 38.8 & 1512 & 42.5 \\
\hline HGBCL-BL like & 81 & 2.5 & 14 & 2.4 & 10 & 2.5 & 24 & 2.5 & 5 & 0.5 & 7 & 1 & 14 & 1.6 & 40 & 8.2 & 2 & 0.3 & 68 & 1.9 \\
\hline Burkitt lymphoma & 131 & 4 & 5 & 0.9 & 3 & 0.8 & 8 & 0.8 & 27 & 3 & 12 & 1.8 & 24 & 2.7 & 8 & 1.6 & 9 & 1.5 & 80 & 2.2 \\
\hline PMLBCL & 36 & 1.1 & N/A & N/A & N/A & $\mathrm{N} / \mathrm{A}$ & 21 & 2.1 & 14 & 1.5 & 13 & 1.9 & 20 & 2.2 & 9 & 1.8 & 14 & 2.4 & 70 & 2 \\
\hline B-LBL & 49 & 1.5 & 1 & 0.2 & 2 & 0.5 & 3 & 0.3 & 22 & 2.4 & 3 & 0.4 & 10 & 1.1 & 1 & 0.2 & 4 & 0.7 & 40 & 1.1 \\
\hline unclassifiable HGBCL & 12 & 0.4 & 4 & 0.7 & 5 & 1.3 & 9 & 0.9 & 8 & 0.9 & 7 & 1 & 32 & 3.6 & 16 & 3.3 & 4 & 0.7 & 67 & 1.9 \\
\hline TCL & 747 & 22.6 & 53 & 9.1 & 38 & 9.5 & 91 & 9.3 & 118 & 12.9 & 121 & 18 & 117 & 13.1 & 69 & 14.2 & 53 & 8.9 & 478 & 13.4 \\
\hline PTCL & 96 & 2.9 & $\mathrm{~N} / \mathrm{A}$ & $\mathrm{N} / \mathrm{A}$ & $\mathrm{N} / \mathrm{A}$ & $\mathrm{N} / \mathrm{A}$ & 25 & 2.6 & 23 & 2.5 & 31 & 4.6 & 24 & 2.7 & 31 & 6.4 & 16 & 2.7 & 125 & 3.5 \\
\hline ENKL & 30 & 0.9 & 3 & 0.5 & 0 & 0 & 3 & 0.3 & 27 & 3 & 35 & 5.2 & 10 & 1.1 & 2 & 0.4 & 5 & 0.8 & 79 & 2.2 \\
\hline T-LBL & 83 & 2.5 & 5 & 0.9 & 8 & 2 & 13 & 1.3 & 14 & 1.5 & 25 & 3.7 & 36 & 4 & 18 & 3.7 & 9 & 1.5 & 102 & 2.9 \\
\hline ALCL & 108 & 3.3 & N/A & N/A & N/A & $\mathrm{N} / \mathrm{A}$ & 22 & 2.2 & 14 & 1.5 & 13 & 1.9 & 29 & 3.3 & 9 & 1.8 & 6 & 1 & 71 & 2 \\
\hline AITCL & 34 & 1 & N/A & N/A & N/A & $\mathrm{N} / \mathrm{A}$ & 12 & 1.2 & 13 & 1.4 & 17 & 2.5 & 6 & 0.7 & 2 & 0.4 & 9 & 1.5 & 47 & 1.3 \\
\hline ATCL & 0 & 0 & 1 & 0.2 & 0 & 0 & 1 & 0.1 & 10 & 1.1 & 0 & 0 & 0 & 0 & 0 & 0 & 0 & 0 & 10 & 0.3 \\
\hline Mature T/NK other & 72 & 2.3 & N/A & N/A & N/A & $\mathrm{N} / \mathrm{A}$ & 5 & 0.5 & 13 & 1.4 & 0 & 0 & 6 & 0.7 & 5 & 1 & 4 & 0.7 & 28 & 0.8 \\
\hline MF & 324 & 9.8 & 1 & 0.2 & 9 & 2.3 & 10 & 1 & 4 & 0.4 & 0 & 0 & 6 & 0.7 & 2 & 0.4 & 4 & 0.7 & 16 & 0.4 \\
\hline
\end{tabular}

N/A: data not available.

BCL: All B-cell lymphomas, LGBCL: low-grade B-cell lymphoma, CLL/SLL: chronic lymphocytic leukemia/small lymphocytic lymphoma, FL: follicular lymphoma, MCL: mantle cell lymphoma, MZL: marginal zone lymphoma, LPL: lymphoplasmacytic lymphoma, HGBCL: high-grade B-cell lymphoma, DLBCL: diffuse large B-cell lymphoma, HGBCL-BL like: high-grade B-cell lymphoma Burkitt lymphoma-like, PMLBCL: primary mediastinal large B-cell lymphoma, B-LBL: B-cell lymphoblastic lymphoma, TCL: all T-cell lymphoma, PTCL: peripheral T-cell lymphoma, NOS, ENKL: extranodal NK-/T cell lymphoma, nasal type, T-LBL: T-cell lymphoblastic lymphoma, ALCL: anaplastic large cell lymphoma, AITCL: angioimmunoblastic T-cell lymphoma, ATCL: adult T-cell leukemia/lymphoma, MF: mycosis fungoides.

WE: West Europe, NA: North America, CSA: Central South America, FE: the Far East, NAF/ME/IN: North Africa/Middle East/India, SAF: South Africa, SEE: Southeast Europe. Developed countries: Combined data of WE and NA. Developing countries: Combined data of CSA, the FE, NAF/ME/IN, SAF, and SEE.

MF has been reported to be associated with professions such as crop and vegetable farming, painting, woodworking, and carpentry and BMI of $>30 \mathrm{~kg} / \mathrm{m}^{2}(19)$. According to the Turkish Statistical Institute, among the working population in Turkey, about one-fifth work in farming industries and one fifth-work in other industrial jobs

(http://www.tuik.gov.tr/PreHaberBultenleri. do?id=18636). Moreover, according to Eurostat 2014 statistics, obesity among people 18 years and over is very high in Turkey (21.2\%), higher than almost all other European countries except Malta (http://ec.europa.eu/ eurostat/tgm/refreshTableAction.do?tab=table\&plugin 
Table 8. Median age presentation of non-Hodgkin lymphomas in Turkey compared to other regions of the world.

\begin{tabular}{|c|c|c|c|c|c|c|c|}
\hline & Turkey & $\begin{array}{l}\text { Developed } \\
\text { countries }\end{array}$ & CSA & $\mathrm{FE}$ & NAF/ME/IN & SA & SEE \\
\hline Low-grade B-cell lymphoma (LGBCL) & 59 & 63 & 63 & 59 & 58 & 58 & 62 \\
\hline High-grade B-cell lymphoma (HGBCL) & 53 & 65 & 58 & 51 & 52 & 43 & 59 \\
\hline T-Cell lymphoma (TCL) & 49 & 52.5 & 46 & 49 & 38.5 & 41 & 49 \\
\hline \multicolumn{8}{|l|}{ P-values (ref: Turkey) } \\
\hline LGBCL & & $<0.001$ & $<0.001$ & 0.96 & 0.27 & 0.27 & $<0.001$ \\
\hline HGBCL & & $<0.001$ & $<0.001$ & 0.14 & 0.77 & $<0.001$ & $<0.001$ \\
\hline TCL & & $<0.001$ & 0.64 & 1.00 & $<0.001$ & $<0.001$ & 1.00 \\
\hline
\end{tabular}

Developed countries: Combined data of Western Europe and North America. CSA: Central South America, FE: the Far East, NAF/ME/ IN: North Africa/Middle East/India, SAF: South Africa, SEE: Southeast Europe.

Table 9. Sex distribution of non-Hodgkin lymphomas in Turkey compared to other regions of the world.

\begin{tabular}{|c|c|c|c|c|c|c|c|c|c|c|c|c|c|c|c|c|}
\hline & \multicolumn{2}{|c|}{ Turkey } & \multicolumn{2}{|c|}{$\begin{array}{l}\text { Developed } \\
\text { countries }\end{array}$} & \multicolumn{2}{|c|}{ CSA } & \multicolumn{2}{|l|}{ FE } & \multicolumn{2}{|c|}{$\begin{array}{l}\text { NAF/ME/ } \\
\text { IN }\end{array}$} & \multicolumn{2}{|l|}{ SAF } & \multicolumn{2}{|l|}{ SEE } & \multicolumn{2}{|c|}{$\begin{array}{l}\text { Developing } \\
\text { countries }\end{array}$} \\
\hline & $\mathrm{n}$ & $\%$ & $\mathrm{n}$ & $\%$ & $\mathrm{n}$ & $\%$ & $\mathrm{n}$ & $\%$ & $\mathrm{n}$ & $\%$ & $\mathrm{n}$ & $\%$ & $\mathrm{n}$ & $\%$ & $\mathrm{n}$ & $\%$ \\
\hline Male & 1873 & 56.9 & 482 & 51.1 & 450 & 50.8 & 417 & 62.3 & 564 & 64 & 277 & 57.5 & 298 & 50.1 & 2006 & 57.1 \\
\hline Female & 1420 & 43.1 & 461 & 48.9 & 436 & 49.2 & 252 & 37.7 & 317 & 36 & 205 & 42.5 & 297 & 49.9 & 1507 & 42.9 \\
\hline p-value (ref: Turkey) & & & \multicolumn{2}{|c|}{0.0017} & \multicolumn{2}{|c|}{0.0012} & \multicolumn{2}{|c|}{0.0092} & \multicolumn{2}{|c|}{0.0001} & \multicolumn{2}{|l|}{0.80} & \multicolumn{2}{|c|}{0.0021} & \multicolumn{2}{|l|}{0.85} \\
\hline
\end{tabular}

Developed countries: Combined data of Western Europe and North America. CSA: Central South America, FE: the Far East, NAF/ME/ IN: North Africa/Middle East/India, SAF: South Africa, SEE: Southeast Europe. Developing countries: Combined data of CSA, the FE, $\mathrm{NAF} / \mathrm{ME} / \mathrm{IN}, \mathrm{SAF}$, and SEE.

$=1 \&$ pcode $=$ sdg_02_10\&language $=$ en) and higher than the average rate of $13 \%$ given for the adult population according to 2016 WHO world data (http://www.who. int/mediacentre/factsheets/fs311/en/). These factors may contribute to the high incidence of MF in Turkey.

The distribution of LGBCL versus HGBCLs was similar to that of CSA, SAF, and developing countries in general. We had significantly more cases of HGBCL and fewer cases of LGBCL in comparison to developed regions of the world and the reverse was true when compared to the Far East and NAF/ME/IN. This could be reflective of our central geographic location with respect to these regions, and is within the general theme of increasing LGBCLs and decreasing HGBCLs towards the west. This general theme parallels changes in socioeconomic status.

Interestingly, even though we had a higher percentage of LGBCL with respect to the east of the globe, we had fewer cases of FL in comparison to almost all regions of the earth with the exception of SEE. FL has been associated with exposure to pesticides and herbicides. The amount of pesticides used in Turkey accounts for a very low percentage of the world usage, which could be one of the reasons behind the low incidence of FL in our study (http:// www.nationmaster.com/country-info/stats/Agriculture/ Pesticide-use). A high rate of transformation to HGBCL and genetic background are other plausible explanations.

Burkitt lymphoma frequency was also higher than in most parts of the world, except CSA. Burkitt lymphoma has been shown to have a higher incidence in developing countries. Factors such as the association of EBV seroconversion at a younger age and a higher seroprevalence within areas of low socioeconomic status are presumed to play a role (20). Seropositivity of EBV is very high in Turkey and was reported to be $99.4 \%$ in a study from the Eastern Anatolian region (21). These factors may have a role in the high frequency of Burkitt lymphoma in Turkey, as well. However, in a previous study, it was found that EBV frequency in DLBCLs was actually more in line with the frequency from developed countries (22). In light of these data it could also be possible that other factors 
that are yet to be discovered affect the frequency of Burkitt lymphoma.

Unclassifiable LGBCLs were significantly higher than in most other regions with the exception of the Far East and South Africa (chi-square, $\mathrm{P}<0.001$ ). We believe that one of the main reasons for this is the fact that all lymphoma cases analyzed in our hospital were included in this group, with a considerable amount of consultation cases with improper quality hindering optimal assessment, low-grade lymphomas being harder to subclassify with low-quality tissue.

Hodgkin lymphomas accounted for almost $20 \%$ of our lymphoma cases, which was a figure significantly higher than that of Southwest China, Australia, Poland, and the United States. This figure, however, was lower than that of Iran (9-13). EBV has been postulated to play a role in the pathogenesis of HLs and most cases of HLs in developing countries are EBV-positive. As mentioned previously, seropositivity of EBV is very high in Turkey (21). This

\section{References}

1. Anderson JR, Armitage JO, Weisenburger DD. Epidemiology of the non-Hodgkin's lymphomas: distributions of the major subtypes differ by geographic locations. Non-Hodgkin's Lymphoma Classification Project. Ann Oncol 1998; 9: 717-720.

2. Alkan C, Kavak P, Somel M, Gokcumen O, Ugurlu S, Saygi C, Dal E, Bugra K, Gungor T, Sahinalp SC et al. Whole genome sequencing of Turkish genomes reveals functional private alleles and impact of genetic interactions with Europe, Asia and Africa. BMC Genomics 2014; 15: 963.

3. Swerdlow SH, Campo E, Pileri SA, Harris NL, Stein H, Siebert R, Advani R, Ghielmini M, Salles GA, Zelenetz AD et al. The 2016 revision of the World Health Organization classification of lymphoid neoplasms. Blood 2016; 127: 2375-2390.

4. Laurini JA, Perry AM, Boilesen E, Diebold J, MacLennan KA, Muller-Hermelink HK, Nathwani BN, Armitage JO, Weisenburger DD. Classification of non-Hodgkin lymphoma in Central and South America: a review of 1028 cases. Blood 2012; 120: 4795-4801.

5. Perry AM, Diebold J, Nathwani BN, MacLennan KA, MullerHermelink HK, Bast M, Boilesen E, Armitage JO, Weisenburger DD. Non-Hodgkin lymphoma in the developing world: review of 4539 cases from the International Non-Hodgkin Lymphoma Classification Project. Haematologica 2016; 101: 1244-1250.

6. Perry AM, Diebold J, Nathwani BN, MacLennan KA, MullerHermelink HK, Bast M, Boilesen E, Armitage JO, Weisenburger DD. Non-Hodgkin lymphoma in the Far East: review of 730 cases from the international non-Hodgkin lymphoma classification project. Ann Hematol 2016; 95: 245-251. high seroprevalence could be associated with the higher frequency of HLs. Data regarding the incidence of EBV in our cases are lacking but a study from the Trakya region reported the presence of EBV in $68.2 \%$ of their HL cases (23).

In summary, we have presented detailed data on the frequency of subtypes of lymphomas based on the review of 4239 cases from a major tertiary center in Turkey and compared these data to those reported from other parts of the world. Our data shed some light on the frequency of lymphoma distribution in Turkey and reveal that the frequencies of MF, Burkitt lymphoma, and HL are considerably higher, whereas FL frequency is considerably lower than in most other parts of the world. Detailed studies that enquire about the medical history, family history, lifestyle factors (including diet), environmental factors, and occupational risk factors of patients with lymphoma are clearly needed in order to shed light on the implications of our data.

7. Perry AM, Perner Y, Diebold J, Nathwani BN, MacLennan KA, Muller-Hermelink HK, Bast M, Boilesen E, Armitage JO, Weisenburger DD. Non-Hodgkin lymphoma in Southern Africa: review of 487 cases from the International NonHodgkin Lymphoma Classification Project. Br J Haematol 2016; 172: 716-723.

8. Perry AM, Diebold J, Nathwani BN, MacLennan KA, MullerHermelink HK, Bast M, Boilesen E, Armitage JO, Weisenburger DD. Relative frequency of non-Hodgkin lymphoma subtypes in selected centres in North Africa, the middle east and India: a review of 971 cases. Br J Haematol 2016; 172: 699-708.

9. Glaser SL, Clarke CA, Keegan TH, Chang ET, Weisenburger DD. Time trends in rates of Hodgkin lymphoma histologic subtypes: true incidence changes or evolving diagnostic practice? Cancer Epidemiol Biomarkers Prev 2015; 24: 14741488.

10. van Leeuwen MT, Turner JJ, Joske DJ, Falster MO, Srasuebkul P, Meagher NS, Grulich AE, Giles GG, Vajdic CM. Lymphoid neoplasm incidence by WHO subtype in Australia 1982-2006. Int J Cancer 2014; 135: 2146-2156.

11. Yang QP, Zhang WY, Yu JB, Zhao S, Xu H, Wang WY, Bi CF, Zuo Z, Wang XQ, Huang J et al. Subtype distribution of lymphomas in Southwest China: analysis of 6,382 cases using WHO classification in a single institution. Diagn Pathol 2011; 6: 77 .

12. Monabati A, Safaei A, Noori S, Mokhtari M, Vahedi A. Subtype distribution of lymphomas in South of Iran, analysis of 1085 cases based on World Health Organization classification. Ann Hematol 2016; 95: 613-618. 
13. Szumera-Cieckiewicz A, Galazka K, Szpor J, Rymkiewicz G, Jesionek-Kupnicka D, Gruchala A, Ziarkiewicz-Wroblewska B, Poniatowska-Broniek G, Demczuk S, Prochorec-Sobieszek M. Distribution of lymphomas in Poland according to World Health Organization classification: analysis of 11718 cases from National Histopathological Lymphoma Register project - the Polish Lymphoma Research Group study. Int J Clin Exp Pathol 2014; 7: 3280-3286.

14. Kilciksiz S, Pehlivan M, Yilmaz EB, Payzin B, Bener S, Baloglu A. The clinical and pathological features of patients with hematological neoplasms: a study of hospital-based cancer registry from western Turkey. J BUON 2011; 16: 505-510.

15. Harris NL, Jaffe ES, Stein H, Banks PM, Chan JK, Cleary ML, Delsol G, De Wolf-Peeters C, Falini B, Gatter KC et al. A revised European-American classification of lymphoid neoplasms: a proposal from the International Lymphoma Study Group. Blood 1994; 84: 1361-1392.

16. Barista I, Tekuzman G, Firat D, Baltali E, Kansu E, Kars A, Ozisik Y, Ruacan S, Uzunalimoglu B, Karaagaoglu E. NonHodgkin's lymphomas in Turkey: eighteen years' experience at the Hacettepe University. Jpn J Cancer Res 1994; 85: 12001207.

17. Sarpel SC, Paydas S, Tuncer I, Varinli S, Koksal M, Akoglu T. Non-Hodgkin's lymphomas in Turkey. Cancer 1988; 62: 16531657.

18. Mertsoylu H, Muallaoglu S, Besen AA, Erdogdu S, Sezer A, Sedef AM, Kose F, Arican A, Ozyilkan O. Primary extranodal non-Hodgkin's lymphoma: clinicopathological features, survival and treatment outcome in two cancer centers of southern Turkey. Asian Pac J Cancer Prev 2014; 15: 7207-7211.
19. Aschebrook-Kilfoy B, Cocco P, La Vecchia C, Chang ET, Vajdic CM, Kadin ME, Spinelli JJ, Morton LM, Kane EV, Sampson JN et al. Medical history, lifestyle, family history, and occupational risk factors for mycosis fungoides and Sezary syndrome: the InterLymph Non-Hodgkin Lymphoma Subtypes Project. J Natl Cancer Inst Monogr 2014; 2014: 98-105.

20. Leoncini LCE, Stein H, Harris NL, Jaffe ES, Kluin PM. Burkitt lymphoma. In: Swerdlow SH, Campo E, Harris NL, Jaffe ES, Pileri SA, Stein H, Thiele J, editors. WHO Classification of Tumours of Haematopoietic and Lymphoid Tissues. Lyon, France: International Agency for Research on Cancer; 2017. pp. 330-331.

21. Ozkan A, Kilic SS, Kalkan A, Ozden M, Demirdag K, Ozdarendeli A. Seropositivity of Epstein-Barr virus in Eastern Anatolian Region of Turkey. Asian Pac J Allergy Immunol 2003; 21: 49-53.

22. Uner A, Akyurek N, Saglam A, Abdullazade S, Uzum N, Onder S, Barista I, Benekli M. The presence of Epstein-Barr virus (EBV) in diffuse large B-cell lymphomas (DLBCLs) in Turkey: special emphasis on 'EBV-positive DLBCL of the elderly'. APMIS 2011; 119: 309-316.

23. Özdil A, Doğanay L, Demir M, Öz Puyan F, Bilgi S. Detection of Epstein Barr Virus in Hodgkin's disease in Trakya Region of Turkey; by in situ hybridization. Turk J Hematol 2002; 19: 461464. 